\title{
MONETARY AWARDS FOR PUBLIC LAW WRONGS: AUSTRALIA'S RESISTANT LEGAL LANDSCAPE
}

\author{
ELLEN ROCK* AND GREG WEEKS ${ }^{* *}$
}

The idea of introducing a monetary remedy for harm arising out of the misdirected exercise of public power has waxed and waned in popularity in Australia over the years. Though few would dispute the intuitive appeal of the sentiment that wrongs should not go unremedied, the question of how harm arising from maladministration could, or should, be repaired remains unresolved. This article canvasses a number of the potential justifications for the creation of such a remedy, before noting the various avenues the Australian courts have considered, and closed down, which might otherwise have led in that direction. These rejected opportunities have included the expansion of existing tort actions, the creation of new causes of action in tort, and the interpretation of statutory remedial powers. Whatever the merit of a remedy on this front, it is clear that it will need to be a matter of legislative, rather than judicial, intervention.

\section{INTRODUCTION}

Fifteen years have passed since Michael Fordham urged that the time was coming to 'grasp [the] nettle' and broach the vexed topic of reparation for maladministration, which he described as 'public law's final frontier'. ${ }^{1}$ The intervening period has seen a waxing and waning of academic interest in the topic, as well as lukewarm enthusiasm for embarking upon law reform. However, in 2018, it seems that we are little closer to addressing the root concerns that have plagued proponents of a public law remedy in damages for decades. With the debate now at risk of going stale for want of legislative attention, ${ }^{2}$ our aim is

\footnotetext{
* Lecturer, University of Technology, Sydney. This research has been in part funded by an Australian Postgraduate Research Scholarship.

** Associate Professor, ANU College of Law.

We would like to thank Mark Aronson, Nina Boughey, Peter Cane, Matthew Groves and Anita Stuhmcke for their helpful comments, as well as this Journal's anonymous referees. All errors are our own.

1 Michael Fordham, 'Reparation for Maladministration: Public Law's Final Frontier' (2003) 8 Judicial Review 104, 108.

2 This is not the only example of legislative inattention effectively ending public law reform; the Administrative Decisions (Judicial Review) Act 1977 (Cth) has long been neglected in the face of calls for
} 
to provoke fresh consideration of the topic by outlining a number of the theoretical justifications that might underpin the introduction of such a remedy, and testing a number of the key arguments that have been raised against such a proposal.

This article sets the parameters in which a revitalised debate might occur by introducing a number of the justifications that will continue to underlie calls to provide a monetary remedy in public law. Moving beyond the intuitive appeal underlying the claim that for every wrong there must be a remedy, other possible justifications for the introduction of public law damages include: historical precedent; the theory of equality before public burdens; or the concept of accountability. We do not take sides on the issue of whether the introduction of a monetary remedy in public law is necessary or desirable. Rather, this article outlines these arguments with a view to encouraging later principled exploration of the barriers that might prevent that development. Whatever the strengths of the case in favour of an administrative law damages remedy, we regard it as clear that any movement on this front will be instigated legislatively, rather than judicially, because the Australian courts have already closed down a range of avenues that might have led to the creation of a monetary remedy for invalid administrative action.

Ultimately, this article aims to provide the impetus for future exploration of the various impediments that have been thrown in the path of developing a monetary remedy in public law. As highlighted in our concluding comments, proposals for reform that have been floated over the years have been challenged on a range of bases. Some of these concerns are pragmatic in nature (for example, claims that there might be overkill and impacts on public resourcing), while others are based in principle (for example, claims that public law damages would produce incoherence in the law and interfere with the separation of powers). If there is any merit in the idea of remedying harm caused by maladministration with damages, then these are the prickly nettles that must eventually be grasped. We leave the detail of addressing such a task to another article.

\section{A MISSING REMEDY?}

A useful starting point in this topic is to think about what omission in existing remedial mechanisms drives the reformist enthusiasm of the proponents of a public law damages remedy. What role would it play that is not otherwise addressed? To understand the nature of the alleged gap in the public law remedies, it is useful to look at the existing legal landscape into which a damages remedy would fit. This article does not propose to offer a comprehensive overview of the various means by which the government can be held liable for its

reform. See, eg, Administrative Review Council, 'Federal Judicial Review in Australia' (Report No 50, September 2012). 
decisions, acts and omissions. ${ }^{3}$ For present purposes, the more important task is to map out the juncture between illegality (ie, where the government has acted in excess of its powers) and liability (ie, where the government can be required to compensate an individual harmed as a result of its illegal act). In this respect, we have developed a taxonomy which considers the four different dynamics at play.

First, a finding of illegality may remove a defence which is otherwise available ('Type 1'). Secondly, the presence of illegality may operate as a threshold enquiry, making it an essential (but not determinative) ingredient in assessing liability ('Type 2'). Thirdly, public law illegality may be a natural corollary of a finding of liability under another regime, even though the courts do not undertake any analysis of whether the conduct contravened a public law ground of review ('Type 3'). Finally, there are some circumstances in which a finding of public law illegality is entirely irrelevant to liability in an alternative regime. The conduct may be invalid without giving rise to liability, or may give rise to liability without being invalid ('Type 4'). In looking at the range of mechanisms that are most frequently pointed to as a source of compensation for an individual harmed by the government, we can identify expressions of each of these types of dynamics. Importantly, however, none of these types of dynamics provides a damages remedy for excess of power per se; it is for this reason that we can regard monetary remedies as missing from the public law arena.

The trespass categories of torts fall most squarely within Type 1, as the question of whether or not an official has acted within the scope of their powers determines whether or not they are able to rely on a defence of legal authority. For example, an official who makes an arrest may rely on the legality of their conduct (such as acting on the basis of a valid arrest warrant) to defend a claim that might otherwise be made in the torts of trespass or battery. Similarly, an official who detains an individual may rely on the legality of their conduct (such as a properly formed reasonable suspicion that the individual is a non-citizen) ${ }^{4}$ to defend a claim made pursuant to the tort of false imprisonment. Perhaps the most difficult aspect of such claims is determining the scope of liability where the source of legal authority relied on (for example, a warrant) is later discovered to have been created ultra vires. Does the subsequent invalidation of that legal authority expose the frontline official who gives effect to the order, and/or the party who initially made the order, ${ }^{5}$ to liability? The crux of the issue was well captured by Simon Brown LJ in Percy v Hall as follows:

That broader question has been well canvassed elsewhere. Relevant considerations include: the scope of governmental immunities, liability for regulatory functions and omissions, distinctions between direct and vicarious liability and the like. See, eg, Mark Aronson, Matthew Groves and Greg Weeks, Judicial Review of Administrative Action and Government Liability (Thomson Reuters, $6^{\text {th }}$ ed, 2017) ch 19; Greg Weeks, Soft Law and Public Authorities: Remedies and Reform (Hart Publishing, 2016) ch 8.

4 As was the case for immigration detention officers in Ruddock v Taylor (2005) 222 CLR 612.

5 As to the potential liability of the author of an invalid instrument, see Ruddock v Taylor (2003) 58 NSWLR 269, 274-7 (Spigelman CJ), reversed on appeal in Ruddock v Taylor (2005) 222 CLR 612. Mr Taylor successfully argued at first instance and on appeal that the Minister, his delegate and immigration officers were liable for false imprisonment in circumstances where the detention scheme was effectively 'self-executing' and detention was the 'inevitable consequence' of the Minister's decision: (2003) 58 
It seems to me one thing to accept, as readily I do, that a subsequent declaration as to [the by-laws'] invalidity operates retrospectively to entitle a person convicted of their breach to have that conviction set aside; quite another to hold that it transforms what, judged at the time, was to be regarded as the lawful discharge of the constables' duty into what must later be found actionably tortious conduct.

In part, the complexity in this area can be traced to historical difficulties of characterising the practical and legal results that flow from a finding that a decision or instrument was made ultra vires. ${ }^{7}$ While an officer may in some cases be entitled to exercise powers in an otherwise tortious manner on the basis that their 'reasonable suspicion' of certain facts causes such acts to be performed validly, ${ }^{8}$ there may be a limit to the reach of this protection. McHugh $\mathrm{J}$ considered one such potential limit in Coleman $v$ Power, ${ }^{9}$ in which the High Court was asked to determine the constitutional validity of legislation creating an offence of using insulting words in a public place, and in turn the validity of $\mathrm{Mr}$ Coleman's arrest. In the minority on the question of the legislation's validity, ${ }^{10}$ McHugh $\mathrm{J}$ observed that because constitutionally invalid legislation is void ab initio, it could not form the basis of a defence of statutory authority: 'a person cannot intend to execute a statutory instrument if the instrument does not exist'. ${ }^{11}$ His Honour went on to explain that ' $[\mathrm{t}] \mathrm{o}$ seek to validate an arrest made in respect of an offence that is invalid under the Constitution is as offensive to the Constitution, as the law that purported to create the offence'. ${ }^{12}$ Accordingly, the question of liability for these categories of torts might be classified as Type 1, but this also depends to some extent on proper characterisation of the relevant type of illegality and interpretation of the applicable statutory scheme.

NSWLR 269, 274, 277 (Spigelman CJ approving the comments of the trial judge). A majority of the High Court held that there was no direct link between the conduct of the Minister and Mr Taylor's imprisonment, because immigration officers detained on the basis of their own 'reasonable suspicion' of Mr Taylor's status: (2005) 222 CLR 612, 622 (Gleeson CJ, Gummow, Hayne and Heydon JJ). Such a limitation on the exercise of statutory powers (which in fact had the status of a duty in that case) is well understood: see George v Rockett (1990) 170 CLR 104. Even if Mr Ruddock had adopted the putative tort after its commission, or ordered it beforehand, the reasonable suspicion premise would have excused him as well as the delegate and detaining officers.

6 [1997] QB 924, 947-8.

7 A good example of this difficulty can be observed in relation to decisions of superior courts in excess of power. In New South Wales v Kable (2013) 252 CLR 118, 133 [32], French CJ, Hayne, Crennan, Kiefel, Bell and Keane JJ noted that:

It is now firmly established by the decisions of this Court that the orders of a federal court which is established as a superior court of record are valid until set aside, even if the orders are made in excess of jurisdiction (whether on constitutional grounds or for reasons of some statutory limitation on jurisdiction). See also $R v$ Governor of Brockhill Prison; Ex parte Evans [No 2] [2001] 2 AC 19, 26 (Lord Slynn). It is also necessary to bear in mind the scope of judicial immunity insofar as the invalid instrument was authored by a judicial officer: Sirros v Moore [1975] QB 118.

8 See, eg, Coleman v Power (2004) 220 CLR 1, 62 [137] (McHugh J).

9 (2004) 220 CLR 1.

10 A majority found that section 7(1)(d) of the Vagrants, Gaming and Other Offences Act 1931 (Qld) did not unduly burden the implied freedom of political communication: ibid 78 (Gummow and Hayne JJ).

11 Coleman v Power (2004) 220 CLR 1, 62 [140] (McHugh J). Kirby J in the same case thought that this principle would be limited to cases of constitutional invalidity: at 101 . 
The tort of misfeasance in public office is an additional means by which citizens can access compensation from government. Though there remains some debate about the scope of the tort,$^{13}$ the view expressed by Lord Millet in Three Rivers District Council v Bank of England [No 3] ${ }^{14}$ was that the tort could be made out in cases of 'targeted malice' (in which case it was unnecessary to demonstrate that the official had acted in excess of their powers), or alternatively, in cases where an official had knowingly or recklessly exceeded their powers with foresight of harm to the plaintiff. ${ }^{15}$ The latter form of the tort involves Type 2 public law illegality, where illegality operates as an essential ingredient (though not determinant) of liability. ${ }^{16}$ In relation to the 'targeted malice' form of the tort, ${ }^{17}$ the plaintiff does not need to demonstrate unlawfulness, and this type of claim therefore falls outside the scope of Type 2. Instead, this form of the tort is Type 3, where public law illegality is not an element of the claim, but where a finding of tortious liability necessarily implies that the official has nonetheless acted in excess of power. This is because any 'malicious' conduct for the purpose of this arm of the tort would of its nature contravene the judicial review grounds of improper purpose and likely also bad faith. ${ }^{18}$

One of the most well-known means of accessing compensation from the government is the tort of negligence. This particular tort has a complex history in respect of its interaction with public law illegality. At various times, public law illegality has played roles involving each of Types 1 to 4 , with movements to incorporate and then disentangle public law principles from the assessment of liability. In England, Geddis v Proprietors of Bann Reservoir was an early authority standing for the proposition that a public body could be liable in negligence for conduct that was otherwise within power. ${ }^{19}$ In other words, negligence removed an otherwise available defence of statutory authority, being

13 And even greater doubt as to how a statutory damages scheme might address this tort. We leave that issue to another day.

14 [2003] 2 AC 1.

15 Ibid 235-6.

16 See Northern Territory v Mengel (1995) 185 CLR 307, 356 (Brennan J) ('Mengel'). The Full Federal Court has rejected the argument that spite or an intention to harm would be insufficient to found liability if the officer's action is otherwise lawful: Nyoni $v$ Shire of Kellerberrin (2017) 248 FCR 311, 329-30 [87] (North and Rares JJ). Their Honours were referring to Mark Aronson, 'Misfeasance in Public Office: Some Unfinished Business' (2016) 132 Law Quarterly Review 427, 441.

17 Lord Sumption remarked in Crawford Adjusters (Cayman) Ltd v Sagicor General Insurance (Cayman) Ltd [2014] AC 366, 416-17 ('Crawford Adjusters') that the requirement to establish targeted malice in cases where misfeasance in public office is alleged makes it, and other malice-based torts such as malicious prosecution, amongst the very limited exceptions to the general rule that malice is irrelevant to tort liability; see Corporation of Bradford v Pickles [1895] 1 Ch 145. More generally, his Lordship gives accurate expression to the chaotic development of the tort of malicious prosecution, an evolution which has continued until so recently that the United Kingdom ('UK') Supreme Court was forced to revist the Privy Council's decision in Crawford Adjusters as a nine member court in Willers $v$ Joyce [2016] 3 WLR 477.

18 The only circumstances in which this would not be the case would be in relation to a power specifically conferred to enable an official to act maliciously; it is inconceivable that the legislature would enact such a law. See Nyoni v Shire of Kellerberrin (2017) 248 FCR 311, 330 [88] (North and Rares JJ). (1878) 3 App Cas 430, 456 (Lord Blackburn). 
a Type 1 cause of action. This principle was revisited in Home Office $v$ Dorset Yacht Co Ltd, ${ }^{20}$ in which members of the House of Lords drew a distinction between liability for the performance of duties and the exercise of discretionary powers. ${ }^{21}$ The former remained within our Type 1, while the latter became Type 2; liability could only attach if the official's conduct fell outside the legal ambit of their discretion. ${ }^{22}$

The notion of public law invalidity as a threshold liability issue in the exercise of discretionary powers (that is, a Type 2 claim) survived until the decision of $X$ (Minors) $v$ Bedfordshire County Council. ${ }^{23}$ In that case, Lord Browne-Wilkinson was critical of the employment of public law concepts in private law, an approach he described as neither 'helpful [n]or necessary'. ${ }^{24}$ However, Lord Browne-Wilkinson then paradoxically ${ }^{25}$ proposed the incorporation of the Wednesbury test of unreasonableness as a determinant of liability in negligence. ${ }^{26}$ This may have maintained a Type 2 approach, under which Wednesbury unreasonableness would operate as a threshold justiciability issue, or may have perhaps represented a move to Type 3, in which Wednesbury would operate not as a threshold question, but as a standard of care affecting assessment of breach of duty. In Stovin v Wise, ${ }^{27}$ Lord Hoffmann adopted the Type 2 approach in introducing a further layer into the enquiry in the form of the distinction between acts and omissions, seemingly requiring that the failure to exercise a power be 'irrational' before liability in negligence might attach. ${ }^{28}$ Since Stovin, further cases have alternately asserted and denied the relevance of public law illegality in the context of government liability in negligence, though the balance appears to favour removal of public law tests as a threshold enquiry. ${ }^{29}$

In Australia, the position prior to the turn of the century was less complex than that in England. Although Brennan CJ favoured the incorporation of public law concepts of illegality into government liability in negligence, ${ }^{30}$ that approach was decisively rejected by a majority in Crimmins $v$ Stevedoring Industry Finance Committee. ${ }^{31}$ This case established that government liability in negligence fell into our Type 4: 'the negligent exercise of a statutory power is not

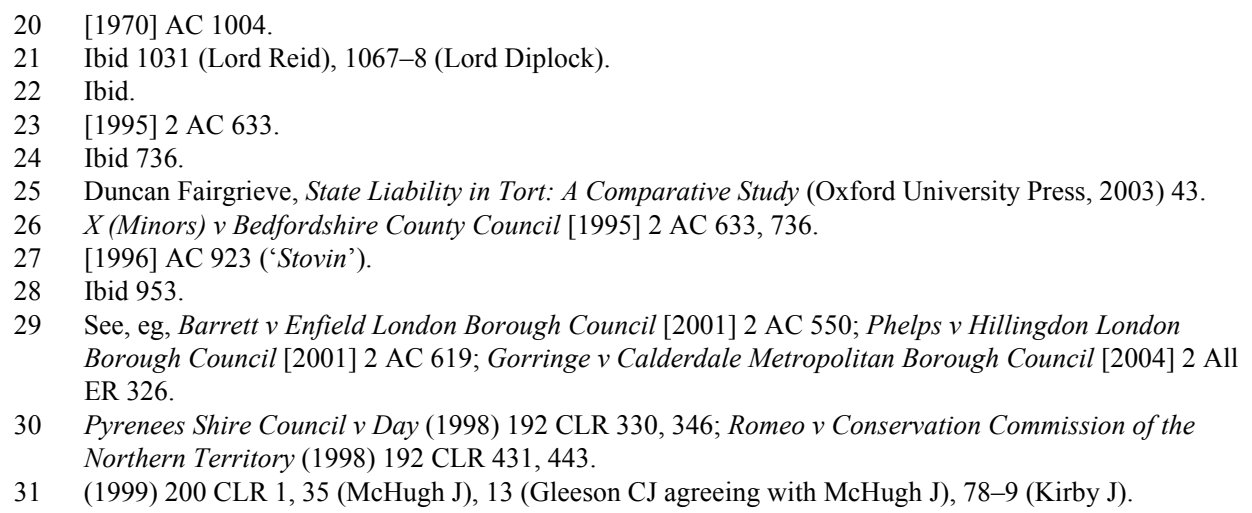


immune from liability simply because it was within power, nor is it actionable in negligence simply because it is ultra vires'. ${ }^{32}$

Instead of relying on public law concepts, the Australian courts subsumed concerns relating to the status of government defendants into the ordinary principles of negligence, rather than dealing with them as stand-alone tests of liability. ${ }^{33}$ The apparent resolution of this debate was thrown again into uncertainty with the introduction of civil liability legislation in a number of Australian States. For example, in NSW, section 43A of the Civil Liability Act 2002 (NSW) introduced the language of Wednesbury unreasonableness into the assessment of government liability for the exercise of 'special statutory powers'. Initial suggestions were that this would introduce what we describe as a Type 2 public law illegality enquiry into the Australian law, pursuant to which Wednesbury unreasonableness would operate as a precondition to liability. ${ }^{34}$ The better view (and that which appears to have been adopted by the courts) ${ }^{35}$ is that the section instead represents an adjustment to the applicable standard of care, being a Type 3 claim in which the high degree of unreasonableness required to establish negligence liability would, by its nature, also render the decision invalid at public law.

Beyond the law of tort, compensation may also be available from the government pursuant to the law of restitution, which may be relevant in cases where an individual has made a payment to the government which the government was not entitled to receive. Under Australian law, restitution may be available where a defendant has been unjustly enriched due to a mistake of fact or law ${ }^{36}$ (which does not assist a plaintiff who correctly believes the demand for payment to have been invalid), ${ }^{37}$ or where the government has exercised a degree of compulsion ${ }^{38}$ (which requires something more than mere invalidity). ${ }^{39}$ These

32 Ibid 35 [82] (McHugh J).

33 Pyrenees Shire Council v Day (1998) 192 CLR 330, 394 (Kirby J).

34 See, eg, Grant Scott Watson, 'Section 43A of the Civil Liability Act 2002 (NSW): Public Law Styled Immunity for the Negligence of Public and Other Authorities?' (2007) 15 Torts Law Journal 153.

35 See, eg, Collins v Clarence Valley Council [No 3] [2013] NSWSC 1682, [100] (Beech-Jones J); Curtis v Harden Shire Council (2014) 88 NSWLR 10, 71 [272] (Basten JA).

36 The High Court rejected the previous distinction between mistakes of fact and mistakes of law in David Securities Pty Ltd v Commonwealth Bank of Australia (1992) 175 CLR 353, 376-9 (Mason CJ, Deane, Toohey, Gaudron and McHugh JJ). It was later removed as a bar to restitution by the House of Lords in Kleinwort Benson Limited v Lincoln City Council [1999] 2 AC 349. However, allowing restitution for mistake of law has created new issues, not least the problems that arise where a valid payment becomes retroactively invalid: James Edelman and Elise Bant, Unjust Enrichment (Hart Publishing, $2^{\text {nd }}$ ed, 2016) 186.

37 Before the bar to restitution for mistake of law was lifted in the UK, this was the very difficulty which faced the plaintiff in Woolwich Equitable Building Society v Inland Revenue Commissioners [1993] AC 70 ('Woolwich').

38 For example, demands made colore officii (under colour of office): Sargood Bros v Commonwealth (1910) 11 CLR 258, 301 (Isaacs J). Before the development of administrative law as we currently understand it, the colore officii cases (eg, Dew v Parsons (1819) 2 B \& Ald 562; Morgan v Palmer (1824) 2 B\&C 729; Steele $v$ Williams (1853) 8 Exch 625) 'firmly controlled ... one species of ultra vires behaviour', being enrichment consequent on making an ultra vires demand: Peter Birks, 'Restitution from the Executive: A Tercentenary Footnote to the Bill of Rights' in P D Finn (ed), Essays on Restitution (Law Book, 1990) 164, 178. 
forms of restitution claim are of Type 2, as demonstrating excess of power is a necessary ingredient of the claim. Importantly, restitution in Australia is not yet available based on invalidity per se. It is in the United Kingdom, in the form of the Woolwich principle. ${ }^{40}$ Although, given the silence of the High Court on the matter, Australian plaintiffs must still work on the assumption that they are required to show something more than mere invalidity in order to obtain restitution, the likelihood ${ }^{41}$ that Woolwich will be adopted in Australia has been discussed both in the Federal Court and various academic publications. ${ }^{42}$ Little stands in its way but the right case reaching the High Court.

Certain non-judicial mechanisms might also operate to provide an individual harmed by the government with access to compensation. One of the more widely recognised examples of such a mechanism is ex gratia compensation, which is made available in Australian jurisdictions under a variety of statutory and executive schemes. ${ }^{43}$ These, and related schemes for waiver of debts and the like, ${ }^{44}$ are inherently discretionary in nature ${ }^{45}$ and expressly do not require public law illegality (therefore comprising Type 4). In fact, payments made pursuant to the two Commonwealth schemes (being the Compensation for Detriment Caused by Defective Administration Scheme and act of grace payments under section 65 of the Public Governance, Performance and Accountability Act 2013 (Cth)) each presuppose that an applicant is not otherwise entitled to restoration from some other source. ${ }^{46}$ In this respect, any question of access to compensation via these mechanisms is independent of the question of invalidity in a public law sense. ${ }^{47}$

39 See, eg, Mason v New South Wales (1959) 102 CLR 108, 142 (Windeyer J).

40 Woolwich [1993] AC 70.

41 Australia's adoption of Woolwich has at times been assumed already to have occurred; see Simone Degeling, 'Restitution of Unlawfully Exacted Tax in Australia: The Woolwich Principle' in Steven Elliott, Birke Häcker and Charles Mitchell (eds), Restitution of Overpaid Tax (Hart Publishing, 2013) 313,314 .

42 See the references cited in Keith Mason, J W Carter and G J Tolhurst, Mason and Carter's Restitution Law in Australia (LexisNexis Butterworths, $3^{\text {rd }}$ ed, 2016) 794 [2021].

43 Public Governance, Performance and Accountability Act 2013 (Cth) s 65 ('PGPA Act'); Commonwealth Department of Finance, 'Scheme for Compensation for Detriment Caused by Defective Administration' (Resource Management Guide No 409, 2017) ('CDDA Scheme Guide'); New South Wales Treasury, 'Ex Gratia Payments' (Treasury Circular No TC11/02, 1 February 2011); Financial Accountability Act 2009 (Qld) ss 65, 72; South Australia Department of Treasury and Finance, 'Ex Gratia Payments' (Treasurer's Instruction No 14, 21 January 2015); Victoria State Government, 'Disclosure of Ex Gratia Expenses' (Financial Reporting Direction No 11A, June 2013); Financial Management Act 1996 (ACT) s 130; Financial Management Act 1995 (NT) s 37; Financial Management Act 2006 (WA) s 80. Tasmania does not have generally applicable statutory provisions for making ex gratia payments or waiving debts, but see the Financial Management and Audit Act 1990 (Tas) ss 13-14.

44 See, eg, Commonwealth Department of Finance, 'Requests for Discretionary Financial Assistance under the Public Governance, Performance and Accountability Act 2013' (Resource Management Guide No 401, April 2018) pts 2-3 ('PGPA Act Discretionary Remedies Guide').

45 It tends for this reason to be of great practical benefit when an ombudsman recommends that a payment be made under a discretionary compensation scheme: Weeks, Soft Law and Public Authorities, above n 3 , 252-3.

46 The CDDA Scheme is not intended to operate in circumstances where the Commonwealth can reasonably be expected to be found liable in litigation or where other avenues of remedy exist: CDDA Scheme Guide, above n 43, 7 [19], [23]. Likewise, an act of grace payment is to be regarded as 'a remedy of last resort', requiring that all other remedial avenues have been exhausted. Legal review mechanisms must be 
What we can take from this discussion is that public law illegality is not determinative of the availability of remedies pursuant to the various judicial and executive mechanisms that we commonly think of as providing a remedy for harm caused by the government. The closest that we come to such a position is the tort of breach of statutory duty, which provides a remedy for harm suffered following breach of a legislative obligation. However, for the reasons discussed below, ${ }^{48}$ this tort has come to be of little practical relevance in this context. Instead, what we see is a series of mechanisms that interact with principles of public law illegality in different ways, but without reaching the position that a remedy is available for loss occasioned as a result of invalidity per se. This is the remedial gap that is under investigation.

\section{THE ALLURE OF PUBLIC LAW DAMAGES}

The inherent appeal underlying the case in favour of extending the reach of compensatory damages to invalid administrative action is summed up in Lord Bingham's much quoted dictum: 'it would require very potent considerations of public policy ... to override the rule of public policy which has first claim on the loyalty of the law: that wrongs should be remedied' ${ }^{49}$

To similar effect was Denning LJ's entreaty: 'I should be sorry to think that, if a wrong has been done, the plaintiff is to go without a remedy simply because no one can find a peg to hang it on, ${ }^{50}$

Notwithstanding the intuitive appeal of these ideas, there is a large leap from this intuition to the creation of a remedy in damages for invalid administrative action. The following discussion sets out some of the grounds which might justify the expansion of public law remedies to provide for compensation: historical precedent, the theories of equality and risk, and the concept of accountability.

\section{A An Historical Mandate}

One reason to think seriously about a potential role for damages in the context of public law wrongs is that it is an approach underwritten by an historical legacy. Before administrative law as we now know it had developed, damages awards in tort actions brought by individual citizens were the primary means of rendering government actors accountable for conduct in excess of

used where a person claims a decision was legally incorrect: PGPA Act Discretionary Remedies Guide, above n 44, 5-6 [3]-[6].

47 Additionally, individual Australian jurisdictions have discretionary compensation schemes directed to specific categories of loss, such as: injuries suffered by victims of crime; institutional sexual abuse; and various categories of loss suffered exclusively or disproportionately by Indigenous Australians, including members of the Stolen Generations. See Part IV(C) below.

49 X (Minors) v Bedfordshire County Council [1995] 2 AC 633, 663 (Lord Bingham).

50 Abbott v Sullivan [1952] 1 All ER 226, 231. 
power. These citizens were frequently justices of the peace and sewer commissioners, both of whom performed a range of administrative functions at the time, respectively issuing licences and making decisions relating to drainage. ${ }^{51}$ The High Court has pointed out on several occasions that questions of validity can still be addressed in tortious actions and not only through judicial review. $^{52}$

Seventeenth century England is often cited as the birthplace of modern judicial review. ${ }^{53}$ In that context, the conferral of power on justices of the peace and sewer commissioners resulted in a proliferation of official conduct that was capable of affecting the rights and interests of the population. ${ }^{54}$ By the $19^{\text {th }}$ century, more formal delegations of power were being made to decision-makers whose specific expertise left them better equipped than the legislative drafters to exercise discretion appropriate to certain circumstances. ${ }^{55}$ To the extent that the exercise of these administrative functions caused injury to a citizen, the only real avenue for recourse was to commence a claim in tort, seeking damages for the harm occasioned. The legality of the official's conduct would be relevant to the assessment of liability. Access to damages was often not the outcome that a citizen was most interested in. Rather, proceedings in tort were in many circumstances commenced for the purpose of testing the validity of the underlying administrative action. ${ }^{56}$ For example, in Fawcett $v$ Fowlis, ${ }^{57}$ the plaintiff brought proceedings in trespass against two magistrates who had convicted the plaintiff of failure to contribute to the upkeep of roads. The real purpose of the proceedings was 'to try the question of liability', 58 being to test the validity of the underlying contribution order and conviction, rather than to seek damages for trespass.

Public law remedies were subsequently developed and adapted, providing a more direct means of challenging the legality of government conduct. From these fused origins, subsequent developments represent an ideological retraction in the shape of this remedial regime, as the doctrinal approaches of judicial review and tort have diverged. Judicial review has become the primary means of testing the

51 Peter Cane, Leighton McDonald and Kristen Rundle, Principles of Administrative Law (Oxford University Press, $3^{\text {rd }}$ ed, 2018) 83.

52 See Commissioner of Australian Federal Police v Propend Finance Pty Ltd (1997) 188 CLR 501, 558 (Gummow J); Corporation of the City of Enfield v Development Assessment Commission (2000) 199 CLR 135, 143-4 [17] (Gleeson CJ, Gummow, Kirby and Hayne JJ); New South Wales v Ibbett (2006) 229 CLR 638, 648 [38] (Gleeson CJ, Gummow, Kirby, Heydon and Crennan JJ); A v New South Wales (2007) 230 CLR 500, 532 [94] (Gleeson CJ, Gummow, Kirby, Hayne, Heydon and Crennan JJ). Amnon Rubinstein, 'On the Origins of Judicial Review' (1964) 2 University of British Columbia Law Review 1, 1-2.

54 Edith G Henderson, Foundations of English Administrative Law: Certiorari and Mandamus in the Seventeenth Century (Harvard University Press, 1963) 2.

55 H W Arthurs, 'Without the Law': Administrative Justice and Legal Pluralism in Nineteenth-Century England (University of Toronto Press, 1985) 136-7; Weeks, Soft Law and Public Authorities, above n 3 , 25.

56 Amnon Rubinstein, Jurisdiction and Illegality: A Study in Public Law (Oxford University Press, 1965) 53 and see especially $\mathrm{n} 1$. This kind of tort proceeding abated "with the proliferation of "no certiorari" clauses': Aronson, Groves and Weeks, above n 3, 29 [2.20].

57 (1827) 7 B \& C 394; 108 ER 770.

58 Ibid 771 (Lord Tenterden CJ). 
validity of administrative action, with the tortious liability of government playing the role of securing compensation. This divergence is also evident in the comparative expansion of judicial review (the increasing popularity of privative and no-invalidity clauses notwithstanding $)^{59}$ and retraction of tortious liability of government throughout the past 50 years. ${ }^{60}$ One question that may be raised by this development is whether, by turning to the more targeted public law remedies, we may have abandoned a remedy that played an effective role in curtailing public abuses of power. ${ }^{61}$

\section{B Equality and Risk}

Two further foundations on which the case for developing a monetary remedy in the context of public law might be made are the notions of equality and risk. In essence, these two rationales reflect the idea that a person ought not to be left to bear the unequal distribution of public burdens or outcomes of dangerous or high-risk public services. ${ }^{62}$ The French system of administrative law is a useful example of the practical application of these ideas, although French institutional arrangements are in distinct contrast to those in Australia. This is primarily because France observes a strict division between the ordinary courts and the administrative law courts, with the latter forming part of the executive branch of government. ${ }^{63}$ All matters involving questions of public law legality (le contentieux de l'annulation) and liability (le contentieux de pleine juridiction) fall within the exclusive jurisdiction of the administrative law courts. $^{64}$

The contrast between the French administrative courts' plenary jurisdiction and the Australian judicial system is of particular interest for discussions about public law damages. The French plenary jurisdiction encompasses traditional categories of fault-based liability, such as tortious liability. ${ }^{65}$ However, the notion of 'fault' in French administrative law encompasses illegality per se, with the effect that 'mere illegality is in itself a fault capable of giving rise to liability

59 Aronson, Groves and Weeks, above n 3, ch 18.

60 David Andrew Ipp et al, 'Review of the Law of Negligence' (Final Report, September 2002) ch 10; Civil Liability Act 2002 (NSW) pt 5.

61 See, eg, Ashby $v$ White (1703) 2 Ld Raym 938; 92 ER 126.

62 See, eg, Peter W Hogg, Patrick J Monahan and Wade K Wright, Liability of the Crown (Carswell, $4^{\text {th }}$ ed, 2011) 214, and in particular n 303.

63 For a detailed overview of the French system of administrative law, see L Neville Brown and John S Bell, French Administrative Law (Clarendon Press, $5^{\text {th }}$ ed, 1998) ch 2.

64 Ibid 130, 180-2, citing Blanco, Tribunal des Conflits, decision $n^{\circ} 00012,8$ February 1873 reported in Rec Lebon 61 and Terrier, Conseil d'État [French Administrative Court], 6 February 1903. The administrative courts have two further areas of jurisdiction: le contentieux de l'interpretátion, which involves proceedings in which the administrative courts are asked to interpret an administrative decision, and le contentiuex de la répression, which involves proceedings commenced by the administration against citizens for particular defined crimes.

65 Ibid 183-5. Note that if the fault is a personal fault of a public official, it will fall to be adjudicated by the ordinary courts: at 186. 
without more', ${ }^{66}$ a correlation that has been described as a 'cornerstone' of French administrative law. ${ }^{67}$

Even more revolutionary, to Australian thinking, is the fact that the French plenary jurisdiction has expanded beyond the notion of fault (taken to include illegality) to allow indemnity on the basis of risk or equality before public burdens (égalité devant les charges publiques) ${ }^{68}$ The rationale underpinning this approach is that even lawful administration in the public interest may impose an unfair burden on an individual that ought to be made the subject of compensation. ${ }^{69}$ Thus, for example, where a port authority lawfully decides not to remove a blockade, a ship owner who suffers loss because it cannot move into port may potentially recover compensation. ${ }^{70}$ Similarly, a company that is forced to discontinue sale of its products following the introduction of a valid law might be entitled to compensation for this loss of trade. ${ }^{71}$ In such cases, the French administrative courts may provide a remedy ${ }^{72}$ irrespective of the legality of the government decision or policy; the foundation of liability is to prevent an individual shouldering that burden alone. There are limits to the reach of the principle, including in connection with the nature of the burden imposed and the loss incurred (which must be regarded as abnormal or special). ${ }^{73}$

Of course, before we could consider adopting such a rationale as a justification for the expansion of government liability in Australia, it would be necessary to grapple with the significant differences in institutional arrangements between these two countries. As noted above, the French administrative courts strictly form part of the executive branch of government for the purpose of conceiving the separation of powers, ${ }^{74}$ in respect of which we might draw a comparison with the Australian tribunal system. Aside from the usual caveats about 'legal transplants' ${ }^{75}$ particular caution is always wise when borrowing

66 Ibid 190.

67 Fairgrieve, above n 25, 28 .

68 Brown and Bell, above n 63, 193-4; ibid 137.

69 Brown and Bell, above n 63, 194.

70 Sealink UK Ltd (CE 22 June 1984), cited in ibid 198. For a case involving similar facts in which the contrary view was reached, see Jokelson et Handstaem (CE 22 June 1984).

71 La Fleurette, Conseil d'État [French Administrative Court], 14 January 1938 reported in [1938] Rec Lebon 25, cited in Brown and Bell, above n 63, 199.

72 For discussion of the French administrative courts' approach to compensation, see, eg, Marie-Aimee Latournerie, 'The Law of France' in John Bell and Anthony W Bradley (eds), Government Liability: A Comparative Study (United Kingdom National Committee of Comparative Law, 1991) 200, 219-22.

73 Fairgrieve, above n 25, 148-9.

74 This fact was the root of Dicey's infamous antipathy to the French and, by extension, to the very idea of 'administrative law' as an affront to the British constitution: A V Dicey, Introduction to the Study of the Law of the Constitution (Macmillan, 10 $\left.0^{\text {th }} \mathrm{ed}, 1959\right)$ 336-8. His preference for the Executive being held accountable in the 'ordinary courts' of England was the result: ibid 187-96. However, the popular view that Dicey did not understand French law is inaccurate; see A V Dicey, 'Droit Administratif in Modern French Law' (1901) 17 Law Quarterly Review 302; Carol Harlow, 'The Influence of Léon Duguit on Anglo-American Legal Thought' in Fabrice Melleray (ed), Autour de Léon Duguit (Bruylant, 2011) 227, 231-2; cf H W Arthurs, 'Rethinking Administrative Law: A Slightly Dicey Business' (1979) 17 Osgoode Hall Law Journal 1, 6-7.

75 See, eg, Carol Harlow, State Liability: Tort Law and Beyond (Oxford University Press, 2004) 43. 
from the French approach to government liability as a source of inspiration for the purpose of fashioning an Australian judicial remedy.

\section{Damages as a Tool of Accountability}

A further possible argument in favour of providing a remedy in damages for public law wrongs is that such an approach is consistent with the concept of accountability. As we have each argued elsewhere, the concept of accountability can be understood as a core value underpinning our system of public law. ${ }^{76}$ While it is a concept that resists clear definition, there is support for the view that accountability is tied to the concept of legitimacy. ${ }^{77}$ On that view, we are more likely to view our system of government as legitimate if the government is held accountable for the way in which it exercises its powers. In a concrete sense, this accountability may be provided by mechanisms within our system of government that facilitate transparency (ie, opening up internal government processes for public scrutiny), control (ie, bringing a misdirected exercise of power back within legal boundaries), punishment (ie, punishing abuses of power) and restoration (ie, restoring interests that have been harmed as a result of misdirected exercises of public power). ${ }^{78}$

If we accept that accountability is enhanced through the pursuit of objectives such as these, it follows that we should wonder how best to achieve them. This article does not propose to enter into the much more difficult normative debate regarding when these various objectives ought to be engaged. ${ }^{79}$ Nor does it argue, even accepting the value of these objectives, that judicial proceedings are necessarily the best vehicle through which they might be pursued. ${ }^{80}$ Rather, this

76 Ellen Rock, 'Accountability: A Core Public Law Value?' (2017) 24 Australian Journal of Administrative Law 189; Janina Boughey and Greg Weeks, 'Government Accountability as a "Constitutional Value"' in Rosalind Dixon (ed), Australian Constitutional Values (Hart Publishing, 2018) 99.

77 See, eg, Frederick M Barnard, Democratic Legitimacy: Plural Values and Political Power (McGill-Queen's University Press, 2001) xi; Mark Bovens, Thomas Schillemans and Paul 't Hart, 'Does Public Accountability Work? An Assessment Tool' (2008) 86 Public Administration 225, 239; Mark Bovens, Deirdre Curtin and Paul 't Hart (eds), The Real World of EU Accountability: What Deficit? (Oxford University Press, 2010) 53.

78 Rock, 'Accountability', above n 76, 194; Ellen Rock, 'Fault and Accountability in Public Law' in Mark Elliott, Jason N E Varuhas and Shona Wilson Stark (eds), The Unity of Public Law? - Doctrinal, Theoretical and Comparative Perspectives (Hart Publishing, 2018) 171, 173-4.

79 For example, if we accept that accountability demands punishment, it is a significant leap to say that every type of transgression by government warrants punishment in that form. For example, we doubt whether accountability would demand punishment in cases where procedural rules have been unknowingly breached, regardless of the fact that such breach results in invalidity for administrative law purposes. The task of deciding when the various objectives of accountability ought to be engaged in a normative sense is a much larger question than that tackled here.

80 For instance, before seriously considering whether accountability demands the expansion of the public law remedial regime, one might think about whether existing judicial mechanisms (eg, liability in tort or criminal law) or non-judicial mechanisms (eg, professional disciplinary proceedings or ex gratia compensation) adequately serve these objectives. Even assuming that they do not, it would be necessary to consider whether a new remedy is most appropriately administered by the courts, or whether it might be better suited to another agency (such as a tribunal or ombudsman etc). A further question not considered in this article is whether the expansion of remedies might potentially contribute to 'accountability overload', a phenomenon in which the culmination of multiple accountability 
article takes as its premise the more general proposition that the provision of a monetary award might contribute to the achievement of these objectives. Most clearly, the provision of compensation is capable of serving the objective of restoration. However, we can also view this remedy as serving a punitive function (as can be seen in the context of punitive damages awards) and to reinforce the control objective by confirming the legal boundaries within which power is to be exercised in future ${ }^{81}$ Accordingly, a damages award has a number of features that are closely aligned with these objectives of accountability.

We are certainly not the first to draw a connection between compensation and government accountability. In the aftermath of the High Court's decision in Mengel, ${ }^{82}$ a number of articles were published in Australian journals, each of them using the tort of misfeasance in public office as a jumping off point to discuss compensatory damages for invalidity. ${ }^{83}$ In one such article, Panetta suggested that: "the introduction of damages as a remedy for merely wrongful administrative decisions causing loss to a plaintiff would represent a natural step in [the] gradual progression towards increasing governmental accountability'. ${ }^{84}$

Cane also referred to the concept of accountability in his exploration of public law damages, suggesting that the 'fundamental tenet' which stands against the availability of damages for public law wrongs 'is no more than a dogmatic assertion which bars consideration of important questions about the relationship between government and its citizens and about the accountability of government'. ${ }^{85}$ Without overstating matters, we can say that the concept of accountability provides a basis upon which the idea of expanding government liability for maladministration might be justified.

Irrespective of the normative foundation of our case, however, it is critical to explore how we might realise these goals. The balance of this article outlines the range of judicial developments that have been ruled out by the courts, leading to the ultimate conclusion that the only possible way forward from this point will be via legislative intervention.

mechanisms leads to negative outcomes, such as discouraging innovation, confused or inconsistent performance and the like: see Arie Halachmi, 'Accountability Overloads' in Mark Bovens, Robert E Goodin and Thomas Schillemans (eds), The Oxford Handbook of Public Accountability (Oxford University Press, 2014) 560.

81 As to the declaratory function of damages in the context of public law wrongs, see, eg, Jason N E Varuhas, 'The Development of the Damages Remedy under the New Zealand Bill of Rights Act 1990: From Torts to Administrative Law' [2016] (1) New Zealand Law Review 213, 238-9.

82 (1995) 185 CLR 307.

83 See, eg, Lachlan Roots, 'Damages for Wrongful Administrative Action: A Future Remedy Needed Now' (1995) 2 Australian Journal of Administrative Law 129; Geoffrey McCarthy, 'Mengel: A Limited Remedy in Damages for Wrongful Administrative Action' (1996) 4 Australian Journal of Administrative Law 5; Rossana Panetta, 'Damages for Wrongful Administrative Decisions' (1999) 6 Australian Journal of Administrative Law 163.

84 Panetta, above n 83, 179.

85 Peter Cane, 'Damages in Public Law' (1999) 9 Otago Law Review 489, 516. 


\section{PUBLIC LAW DAMAGES JUDICIALLY REJECTED}

Lord Bingham's statement that all 'wrongs should be remedied" ${ }^{86}$ has been well-received, although not universally so. In an extra-curial speech, Lord Hoffmann said:

I yield to no one in my admiration for Lord Bingham, but I am bound to say that [Lord Bingham's dictum] is as question-begging a statement as you could find. By what procedure should they be remedied; what should the remedy be; at whose expense should they be remedied? Should the law provide that every wrong should be remedied from the public purse? Because we are lawyers, does that mean that an action for damages is obviously the only right way of remedying a wrong? ${ }^{87}$

His Lordship has not been alone in expressing such doubts. Australian courts have been presented with a range of opportunities over the past half century to develop a remedy providing for restoration of harm arising out of administrative illegality. None of these opportunities has been taken up, with the courts expressing reluctance to take on the task of finding the appropriate 'peg' within either public or private law upon which to hang the remedy. We can point to several examples.

First, the High Court developed, but soon disapproved and ultimately put an end $^{88}$ to the (much maligned) Beaudesert tort, ${ }^{89}$ which might have provided a remedy for harm caused by invalid administrative activity but was instead the cause of immense judicial disquiet. Secondly, the courts have maintained a strict hold on the mental elements of the tort of misfeasance in public office, refusing to expand the reach of the tort beyond cases of intentional (or subjectively reckless) excess of power. Thirdly, the courts have adopted an extremely strict approach to the task of interpreting whether the legislature intended to provide a civil remedy for the purpose of the tort of breach of statutory duty. Fourthly, the Australian judiciary has refused to follow the lead of other common law countries in providing a remedy for damages based on breach of constitutional norms. Finally, the courts have refused the invitation to interpret a broad remedial power in judicial review legislation as incorporating the power to award damages. Under Australian law, the status quo is well reflected in Einfeld J's statement in Chan Yee Kin v Minister for Immigration, Local Government and Ethnic Affairs, that 'the mere invalidation of an administrative decision does not provide a cause of action or a basis for an award of damages'.$^{90}$ All of this signals, in no uncertain terms, that any development of a monetary remedy for public law wrongs must at least commence through legislative, rather than judicial, intervention.

$86 X$ (Minors) v Bedfordshire County Council [1995] 2 AC 633, 663.

87 Lord Hoffmann, 'Reforming the Law of Public Authority Negligence' (Speech delivered at the Bar Council Law Reform Lecture, London, UK, 17 November 2009) [20].

88 Mengel (1995) 185 CLR 307.

89 Beaudesert Shire Council v Smith (1966) 120 CLR 145 ('Beaudesert').

90 (1991) 31 FCR 29, 41. 


\section{A Beaudesert: A Tort Providing Compensation for Loss Caused by Invalidity Per Se}

As outlined in our definition of the Type 4 remedial mechanism in Part II above, the validity of an administrative act is generally irrelevant to tort law liability $;{ }^{91}$ in the words of Lord Goff, "there is no general right to indemnity by reason of damage suffered through invalid administrative action'. ${ }^{92}$ Sometimes the absence of legal justification for an act will be a necessary element in making out a tort claim, ${ }^{93}$ but the fact that an act or decision is invalid in the public law sense is never sufficient per se to ground liability in tort. This has long been the orthodox position. One possible way of extending the capacity to obtain monetary remedies from public authorities would be to make invalidity itself a compensable wrong. The High Court in Beaudesert contemplated the possibility of developing such a freestanding tort, ${ }^{94}$ which would provide:

independently of trespass, negligence or nuisance but by an action for damages upon the case, [that] a person who suffers harm or loss as the inevitable consequence of the unlawful, intentional and positive acts of another is entitled to recover damages from that other. ${ }^{95}$

The two critical elements of this 'embryonic' tort ${ }^{96}$ would have been first, that the wrongdoer must have acted 'unlawfully', 'intentionally' and 'positively', and secondly, that the plaintiff must have suffered loss as an 'inevitable consequence' of that conduct. The aspect of this tort that proved the most vexing was the question of what was meant by 'unlawful'. Was the Court referring to 'an act forbidden by law or, simply, an unauthorised act in the sense of an act that is ultra vires and void'? ${ }^{97}$ The High Court in Mengel preferred the narrower reading, with the effect that there could be no liability without an act forbidden by law (as opposed to one which is merely invalid). ${ }^{98}$

While some may have been justifiably 'greatly encouraged' by Beaudesert because the High Court had enunciated a 'general principle of liability for invalid

91 Brennan CJ suggested that a public authority's liability for either negligence or breach of statutory duty might require that the plaintiff prove that the public authority had acted ultra vires, perhaps for unreasonableness in the sense described in Associated Provincial Picture Houses Ltd $v$ Wednesbury Corporation [1948] 1 KB 223; Pyrenees Shire Council v Day (1998) 192 CLR 330, 344-7; Romeo v Conservation Commission of the Northern Territory (1998) 192 CLR 431, 443-4. His Honour's dicta built upon English precedent in Home Office v Dorset Yacht Co Ltd [1970] AC 1004, 1068 (Lord Diplock) and Stovin [1996] AC 923, 953 (Lord Hoffmann), but has not commanded broad support in Australia: see Aronson, Groves and Weeks, above n 3, 1125 [19.340]; Greg Weeks, 'A Marriage of Strangers: The Wednesbury Standard in Tort Law' [2010] (8) Macquarie Journal of Business Law 131, $135-40$.

$92 R v$ Secretary of State for Transport; Ex parte Factortame Ltd [No 2] [1991] 1 AC 603, 672.

93 Such as for false imprisonment: see $R$ (Lumba) $v$ Secretary of State for the Home Department [2012] 1 AC 245.

94 The tort described by the Court in Beaudesert has been referred to as an 'innominate tort': see Dunlop v Woollahra Municipal Council [1982] AC 158, 170.

95 Beaudesert (1966) 120 CLR 145, 156.

96 Mengel (1995) 185 CLR 307, 343 (Mason CJ, Dawson, Toohey, Gaudron and McHugh JJ).

97 Ibid 336 (Mason CJ, Dawson, Toohey, Gaudron and McHugh JJ).

98 Ibid. 
administrative action', ${ }^{99}$ the general reception was 'icy'. ${ }^{100}$ Academic criticism was almost immediate; ${ }^{101}$ the first judicial revisions came shortly after; ${ }^{102}$ and less than a decade after that, the Privy Council first cast fairly emphatic doubt on the Beaudesert principle ${ }^{103}$ before rejecting it altogether four months later. ${ }^{104} \mathrm{It}$ was, then, wholly unsurprising when the High Court in Mengel overturned Beaudesert less than three decades after it had first been decided; the only surprise was that it had taken so long at all. As Barton remarked almost a decade before Beaudesert was finally terminated:

Those cases that have considered Beaudesert have stripped it of any real impact. As a result of twenty years explaining and distinguishing Beaudesert now stands for little more than an example of the distinction between an action in trespass and an action upon the case. ${ }^{10}$

While we share Barton's view that Beaudesert served as a catalyst for 'discussions and debates' which assist in defining the principles at stake 'with greater clarity', ${ }^{106}$ the fact remains that, three decades after he expressed that view, the judiciary is virtually silent in contributing to discussion of this legal principle. ${ }^{107}$ The distaste that Beaudesert provoked almost immediately after it was decided has not dissipated over time.

\section{B Misfeasance in Public Office: Reducing the Fault Burden}

Modification of the tort of misfeasance in public office is a further possible means by which damages might be made available in a wider array of cases involving ultra vires conduct. In Mengel, Deane J concisely summed up the elements of the tort as follows: '(i) an invalid or unauthorised act; (ii) done

99 G P Barton, 'Damages in Administrative Law' in Michael Taggart (ed), Judicial Review of Administrative Action in the 1980s: Problems and Prospects (Oxford University Press, 1986) 123, 131.

100 Ibid 132. Harlow said with some understatement that 'the case is not beloved of the judiciary': Carol Harlow, Compensation and Government Torts (Sweet \& Maxwell, 1982) 67.

101 Gerald Dworkin and Abraham Harari, 'The Beaudesert Decision - Raising the Ghost of the Action upon the Case: Part I' (1967) 40 Australian Law Journal 296; Gerald Dworkin and Abraham Harari, 'The Beaudesert Decision - Raising the Ghost of the Action upon the Case: Part II' (1967) 40 Australian Law Journal 347.

102 'It seems to me that for the plaintiff to succeed in his special action on the case he must show something more than a mere breach of the statute and consequential damage; he must show something over and above what would ground liability for breach of statutory duty if the action were available. As I see the case, he has not succeeded in showing that the act was tortious (and not merely a contravention of the statute), that its inevitable consequence was to cause damage to the plaintiff, or that there was an intention to cause harm to the plaintiff': Kitano v Commonwealth (1974) 129 CLR 151, 174-5 (Mason J).

103 Dunlop v Woollahra Municipal Council [1982] AC 158, 170-1 (Privy Council).

104 Lonrho Ltd v Shell Petroleum Co Ltd [No 2] [1982] AC 173.

105 Barton, above n 99, 135.

106 Ibid.

107 Hayne J referred to Beaudesert as a 'temporary diversion' in Perre v Apand Pty Ltd (1999) 198 CLR 180, 306 [347]. Gleeson CJ, Gaudron, Kirby and Hayne JJ referred briefly to the reasons for which Mengel had overturned Beaudesert in Sanders v Snell (1998) 196 CLR 329, 343-4 [35]. Leaving aside these exceptions, no Australian court has mentioned Beaudesert since the High Court's decision in Mengel (and it was not mentioned frequently before Mengel either). 
maliciously; (iii) by a public officer; (iv) in the purported discharge of his or her public duties; (v) which causes loss or harm to the plaintiff'. ${ }^{108}$

The mental element of the tort has been described as comprising two alternative limbs. ${ }^{109}$ The first is that of 'targeted malice', which captures 'actual intention to cause injury', 110 or conduct either 'specifically intended to injure a person" ${ }^{111}$ or engaged in "with the predominant intent of damaging a person'. ${ }^{12}$ The second limb, which addresses a knowing or recklessly unlawful act that causes damage, captures both deliberate wrongdoing and recklessness in the sense of 'deliberate blindness'. ${ }^{113}$

Until recently, there had been some doubt as to whether an official was only liable for damage that they actually foresaw, or whether liability also extended to damage that an official ought to have foreseen. ${ }^{114}$ In Obeid $v$ Lockley, the NSW Court of Appeal was firmly of the view that the misfeasance tort requires a plaintiff to establish that the defendant was aware their conduct would cause harm, or were recklessly indifferent to such a risk. ${ }^{115}$ This insistence on proof of subjective awareness of harm prevents the tort from expanding to capture an official who recklessly exceeds their powers in circumstances where they ought to have foreseen the possibility of harm arising.

Because the tort of misfeasance in public office contemplates damages for ultra vires conduct, it is unsurprising that it has proved a beacon for academic consideration of compensatory damages as a remedy for 'wrongful' administrative action or maladministration. ${ }^{116}$ However, the courts have shown little inclination to lower the grade of the mental element beyond the strict bar set in Mengel, both in relation to awareness of illegality and awareness of harm. The degree of "conscious maladministration' 117 required to make out a claim of misfeasance (and satisfy the accompanying evidentiary burden) means that this tort is likely to continue to play only a residual role in providing compensation for public law wrongs.

108 Mengel (1995) 185 CLR 307, 370. Aronson noted that Deane J's summary of the tort (at 370-1) came closest to an explicit affirmation of the usually implicit view that 'the alternative mental elements (targeted malice, knowledge and conscious indifference) comprise a closed list of the types of fault sufficient to warrant an action for misfeasance': Mark Aronson, 'Misfeasance in Public Office: A Very Peculiar Tort' (2011) 35 Melbourne University Law Review 1, 22.

109 Three Rivers District Council v Bank of England [No 3] [2003] 2 AC 1, 137 (Auld LJ). In the House of Lords, both Lord Hobhouse (at 230) and Lord Millett (at 235) viewed the mental elements suggested by Deane J merely as examples 'of the types of dishonesty or want of good faith that the tort requires': Aronson, 'Misfeasance in Public Office: A Very Peculiar Tort' above n 108.

110 Mengel (1995) 185 CLR 307, 370 (Deane J).

111 Three Rivers District Council v Bank of England [No 3] [2003] 2 AC 1, 191 (Lord Steyn).

112 Ibid 137 (Auld LJ).

113 Mengel (1995) 185 CLR 307, 371 (Deane J).

114 See, eg, South Australia v Lampard-Trevorrow (2010) 106 SASR 331, 387-8 [263] (The Court); Aronson, Groves and Weeks, above n 3, 1151-2 [19.650]; Alison Doecke, 'Misfeasance in Public Office: Foreseen or Foreseeable Harm' (2014) 22 Torts Law Journal 20.

115 (2018) 355 ALR 615, 648-53 [153]-[172] (Bathurst CJ), 665-7 [242] (Leeming JA).

116 See above $\mathrm{n} 83$.

117 Pyrenees Shire Council v Day (1998) 192 CLR 330, 375 [124] (Gummow J); Federal Commissioner of Taxation v Futuris Corporation Ltd (2008) 237 CLR 146, 153-4 [11]-[15], 157 [25] (Gummow, Hayne, Heydon and Crennan JJ). 


\section{The Tort of Breach of Statutory Duty}

A third tort that may have opened the path towards a general remedy in damages for excess of public power is the tort of breach of statutory duty. As a matter of historical interest: "the common law was once willing to adopt the simple principle that the breach of a duty created by a statute, if it results in damage to an individual, is a tort for which an action for damages will lie at his suit ....118

On that approach, the government would be liable for any loss occasioned through the misdirected exercise of a duty set out in legislation. However, Harlow described breach of statutory duty as a 'missing tort' because the scope of liability for harm caused by such breaches had, even by 1982, become so hedged about with qualifications that the tort was of little meaningful value for the purpose of obtaining a remedy for the misdirected exercise of public power. ${ }^{119}$ The matter can be phrased in the opposite way, by stating that breach of statutory duty has been 'starved of attention in negligence's considerable shadow' and 'is a cause of action which shows little sign of life outside its original area of workplace safety law'. ${ }^{20}$

The most problematic aspect of breach of statutory duty has been its focus on parliamentary intention, ${ }^{121}$ as the tort is relevant only where it can be said that parliament intended to impose liability upon a defendant ${ }^{122}$ through a private cause of action where a statutory duty had been breached. This may be the case, for instance, if the statute was designed to prevent the kind of harm suffered by the plaintiff, ${ }^{123}$ or could be read as imposing a duty for the benefit of a particular class of persons, ${ }^{124}$ as opposed to protecting the 'general public interest' ${ }^{125}$ In the context of government liability, the court may also take into account competing interests:

[T] here is a need to balance the protection of liberty and due process with the need for public officials to carry out their obligations honestly and in good faith free from the fear of actions for damages, either against themselves or their employers who would normally be vicariously liable. ${ }^{126}$

118 Sir John William Salmond et al, Salmond and Heuston on the Law of Torts (Sweet \& Maxwell, $21^{\text {st }}$ ed, 1996) 247, cited in Harlow, Compensation and Government Torts, above n 100, 68 (citing previous edition).

119 Harlow, Compensation and Government Torts, above n 100, 68-70.

120 Aronson, Groves and Weeks, above n 3, 1131 [19.400]-[19.410]. In R (Canada) v Saskatchewan Wheat Pool [1983] 1 SCR 205, the Canadian Supreme Court isolated the tort to industrial saftety legislation, which was widely understood as virtually killing it off. However, the more recent decision in Cooper $v$ Hobart [2001] 3 SCR 537 might have breathed some new life back into it.

121 O'Connor v SP Bray Ltd (1937) 56 CLR 464, 477-8 (Dixon J); Byrne and Frew v Australian Airlines Ltd (1995) 185 CLR 410, 424 (Brennan CJ, Dawson and Toohey JJ).

122 Darling Island Stevedoring and Lighterage Co Ltd v Long (1957) 97 CLR 36.

123 Mummery v Irvings Pty Ltd (1956) 96 CLR 99.

124 Read v Croydon Corporation [1938] 4 All ER 631.

125 Chordas v Bryant (Wellington) Pty Ltd (1988) 20 FCR 91, 102 (The Court).

126 Chan Yee Kin v Minister for Immigration, Local Government and Ethnic Affairs (1991) 31 FCR 29, 38 (Einfeld J). 
Ultimately, the task of divining parliamentary intention and balancing competing concerns such as these has left the tort with perhaps even less of a role to play in the context of government liability than in general.

It has been suggested that one way of bringing clarity to the tort would be to apply an interpretive presumption that a breach of statutory duty is intended (or not intended) to sound in damages unless the contrary intention appears. ${ }^{127}$ Certainly the use of such a tool of interpretation would simplify matters. However, an added benefit of the use of a presumption in favour of liability would be to bolster government accountability. As with the principle of legality more generally, Parliament would be obliged 'squarely [to] confront what it is doing and accept the political cost'. ${ }^{128}$ This argument gathers strength in the modern Australian context given that the way that parliamentary 'intent' is determined has shifted from a search for any actual intention on the part of legislators ${ }^{129}$ to the application of principles and presumptions to the 'construct' of legislative intention. ${ }^{130}$

Whatever the merits of these views, however, the courts' approach to government liability for the tort of breach of statutory duty in modern times has been dismissive. Further, we note that legislative intervention in this area has had the effect of making a claim even more difficult, in requiring a plaintiff to demonstrate that the nature of the breach was 'so unreasonable that no authority ... could properly consider [it] to be a reasonable exercise of its functions' ${ }^{131} \mathrm{In}$ light of these developments, we see no prospect of the expansion of this tort so as to provide a remedy for invalid administrative action per se.

\section{A Constitutional Tort?}

A number of other common law jurisdictions, one of the most notable being the United States, provide a damages remedy for breaches of constitutional norms, a cause of action that has been described as a 'constitutional tort'. The Constitution of the United States does not provide an express remedy for its breach. ${ }^{132}$ The so-called 'constitutional torts' were developed later, ${ }^{133}$ and include a common law right to damages for violations by federal officers, known as the 'Bivens action'. ${ }^{134}$ The Bivens case itself involved a claim for damages brought following an unauthorised search by Federal narcotics agents. The Supreme

127 See, eg, Harlow, Compensation and Government Torts, above n 100, 69-70; Alec Samuels, 'Is a Breach of Statutory Duty Actionable?' (1995) 16 Statute Law Review 225.

$128 R v$ Secretary of State for the Home Department; Ex parte Simms [2000] 2 AC 115, 131 (Lord Hoffmann).

129 See Corporate Affairs Commission (NSW) v Yuill (1991) 172 CLR 319, 339-40 (Gaudron J), 345-6 (McHugh J).

130 Chief Justice Robert French, 'Litigating in a Statutory Universe' (Speech delivered at the Victorian Bar Association $2^{\text {nd }}$ Annual CPD Conference, Melbourne, 18 February 2012).

131 Civil Liability Act 2002 (NSW) s 43.

132 Hogg, Monahan and Wright, above n 62, 202.

133 The first was the statutory right to damages for violations by State officers pursuant to the Civil Rights Act of 1871: Civil Action for Deprivation of Rights, 42 USC $\S 1983$ (2006).

134 Named for the landmark case in which the Supreme Court first established the principle: Bivens $v$ Six Unknown Named Agents of Federal Bureau of Narcotics, 403 US 388 (1971) ('Bivens'). 
Court found that a damages claim against the agents was maintainable on the basis of the contravention of Mr Bivens' fourth amendment rights. ${ }^{135}$ Such a claim does not operate on the principle of vicarious liability, ${ }^{136}$ but is a proceeding directly against the individual officer who infringed the relevant constitutional right. ${ }^{137}$ To make out a Bivens action, the plaintiff must have been deprived of a right guaranteed by the Constitution by a federal officer acting within the scope of federal law.

One of the main mechanisms by which the courts reject Bivens claims is if 'special factors' tend against a remedy, ${ }^{138}$ a test whose application effectively leaves Bivens with a role to play only where Congress has not otherwise indicated (expressly or impliedly) its intention to deal with remedies for breaches of particular constitutional rights. ${ }^{139}$ The Supreme Court has since clarified that the scope of the enquiry is to be concentrated 'on whether the Judiciary is well suited, absent congressional action or instruction, to consider and weigh the costs and benefits of allowing a damages action to proceed'. ${ }^{140}$ There will also be no Bivens liability if the defendant enjoys an immunity. Absolute immunity applies to government officers who are engaged in 'special functions" ${ }^{141}$ and is focussed on the character of the power being exercised. By contrast, qualified immunity is concerned with the manner in which the power is exercised and immunises government officials if 'their conduct does not violate clearly established statutory or constitutional rights of which a reasonable person would have known' ${ }^{142}$ In other words, there is no liability in circumstances where the content of the applicable constitutional right or derivative legal obligation is not welldefined or remains open to interpretation.

135 A holding subsequently extended to apply to other constitutional rights, including those protected by the fifth and eighth amendments: Davis v Passman, 442 US 228 (1979) and Carlson v Green, 446 US 14 (1980), cited in Alexander A Reinert, 'Measuring the Success of Bivens Litigation and Its Consequences for the Individual Liability Model' (2010) 62 Stanford Law Review 809, 822. However, these are the only cases since Bivens in which the Supreme Court has awarded non-statutory tortious damages. See Hogg, Monahan and Wright, above n 62, 201-2; Jason N E Varuhas, Damages and Human Rights (Hart Publishing, 2016) 468.

136 Although in many circumstances individual officers are indemnified by their government employer; see, eg, Barbara E Armacost, 'Qualified Immunity: Ignorance Excused' (1998) 51 Vanderbilt Law Review 583,665 .

137 As opposed to the government at large, with the exception that the statutory cause of action against state officers extends also to municipalities: Reinert, above $\mathrm{n} 135,811$ and text accompanying $\mathrm{n} 6$.

138 In Bivens itself, the Court made only the rather cursory statement that there were 'no special factors counselling hesitation in the absence of affirmative action by Congress' but did not go into detail about what this meant: Bivens 403 US 388, 396 (1971). A small number of cases were later cited as examples of circumstances that presumably involved 'special factors', eg, United States $v$ Standard Oil Company of California, 332 US 301 (1947) and United States v Gilman, 347 US 507 (1954).

139 Anya Bernstein, 'Congressional Will and the Role of the Executive in Bivens Actions: What Is Special about Special Factors?' (2011) 45 Indiana Law Review 719, 720-1.

140 Ziglar v Abbasi (S Ct, No 15-1538, 19 June 2017) slip op 12-13.

141 Including the activities of legislators, judges, prosecutors and the President: Janell M Byrd, 'Rejecting Absolute Immunity for Federal Officials' (1983) 71 California Law Review 1707, 1714-15.

142 Harlow v Fitzgerald, 457 US 800, 818 (1982), cited in Armacost, above n 136, 619. As reflected in the wording 'would have known', the test is applied objectively rather than subjectively and invites an assessment of the reasonableness of the official's conduct. 
Despite early excitement regarding the game-changing role that Bivens actions could play in relation to constitutional violations, many now consider the cause of action to be somewhat of a dead letter in the United States. ${ }^{143}$ In Australia, which has no specifically public torts other than misfeasance in public office, the High Court has resoundingly rejected arguments that a remedy in the style of that applied in Bivens ought to be made available for conduct in breach of the Australian Constitution. ${ }^{144}$ There are two reasons why we should not be surprised by this. First, much of the focus of the Australian High Court has in recent decades centred on the so-called 'constitutional writs'. ${ }^{145}$ To ask the Court to develop a remedy in damages for breach of the Constitution would require the Court to look beyond the scope and purpose of the named writs and this would be at odds with recent jurisprudence. Secondly, the Australian Constitution includes few express rights ${ }^{146}$ and protects them in a conditional fashion. ${ }^{147}$ Countries like Canada and New Zealand, which protect individual rights either explicitly or implicitly through constitutional rights instruments, ${ }^{148}$ have a greater capacity to follow the trail blazed in Bivens. ${ }^{149}$

In James $v$ Commonwealth, ${ }^{150}$ the High Court considered a claim for damages based on the argument that section 92 of the Constitution conferred some form of rights on the plaintiff to trade without impediment, and that the enactment of legislation which fell afoul of section 92 breached that right. In rejecting this argument, Dixon J stated:

Prima facie a constitution is concerned with the powers and functions of government and the restraints upon their exercise. There is, in my opinion, no sufficient reason to regard sec 92 as including among its purposes the creation of private rights sounding in damages ...

The argument was raised again in Kruger $v$ Commonwealth, ${ }^{152}$ where the plaintiffs sought damages relating to the removal and detention of Indigenous

143 In Correctional Services Corp v Malesko, 534 US 61, 75 (2001), Scalia J described the Bivens action as a 'relic of ... heady days'. But Reinert argues that on closer examination, the success rate of Bivens actions is in the order of 16 per cent to more than 40 per cent: Reinert, above n 135, 813 .

144 Lange v Australian Broadcasting Corporation (1997) 189 CLR 520, 563 (The Court); Kruger v Commonwealth (1997) 190 CLR 1, 46-7 (Brennan CJ), 93 (Toohey J), 125-6 (Gaudron J) and 146-8 (Gummow J); British American Tobacco Australia Ltd v Western Australia (2003) 217 CLR 30, 52-3 (McHugh, Gummow and Hayne JJ); Mulholland v Australian Electoral Commission (2004) 220 CLR 181, 245 (Gummow and Hayne JJ); Aid/Watch Inc $v$ Commissioner of Taxation of the Commonwealth of Australia (2010) 241 CLR 539, 556 (French CJ, Gummow, Hayne, Crennan and Bell JJ). Only Kirby J has expressed a preference for Australia following the approach taken in the USA and New Zealand: British American Tobacco Australia Ltd v Western Australia (2003) 217 CLR 30, 79.

145 Re Refugee Review Tribunal; Ex parte Aala (2000) 204 CLR 82, 92-3 (Gaudron and Gummow JJ).

146 Such 'rights' as the Australian Constitution does contain are better characterised as negative limits on legislative and executive power, rather than as rights to be enjoyed by the individual.

147 See James Stellios, Zines's The High Court and the Constitution (Federation Press, $6^{\text {th }}$ ed, 2015) 553-4.

148 See Hogg, Monahan and Wright, above n 62, 202-3.

149 In the celebrated Canadian case of Vancouver (City) $v$ Ward [2010] 2 SCR 28, the plaintiff was able to obtain damages for breach of the Canadian Charter of Rights and Freedoms in circumstances where police had subjected him to a strip search on suspicion that he intended to throw a pie at the Prime Minister.

$150 \quad$ (1939) 62 CLR 339.

151 Ibid 362.

152 (1997) 190 CLR 1. 
children pursuant to legislation which was argued to be invalid on a number of bases, including that the legislation was contrary to various provisions of the Constitution. Though the High Court dismissed the claim of invalidity, several of the judgments referred to the issue of whether contravention of the Constitution would have afforded a right to damages in any event. Brennan CJ put the position as follows:

The Constitution creates no private rights enforceable directly by an action for damages ... The Constitution reveals no intention to create a private right of action for damages for an attempt to exceed the powers it confers or to ignore the restraints it imposes ... If a government does or omits to do anything which, under the general law, would expose it or its servants or agents to a liability in damages, an attempt to deny or to escape that liability fails when justification for the act done or omission made depends on a statute or an action that is invalid for want of constitutional support. In such a case, liability is not incurred for breach of a constitutional right but by operation of the general law. But if a government does or omits to do something the doing or omission of which attracts no liability under the general law, no liability in damages for doing or omitting to do that thing is imposed on the government by the Constitution.

In other words, the exercise of legislative power in excess of constitutional limits is not, of itself, a wrong that sounds in damages, though an invalid law cannot immunise conduct which would otherwise be wrongful within the meaning of the general law.

\section{E Interpretation of the Power to Make Orders Pursuant to Section 16 of the $A D J R$ Act}

The question of whether damages might be available as a remedy for invalid administrative action has arisen under section 16(1)(d) of the Administrative Decisions (Judicial Review) Act 1977 (Cth) ('ADJR Act'). The ADJR Act has been described as 'overwhelmingly beneficial" ${ }^{154}$ and as featuring a 'flexible and expanded remedial framework' ${ }^{155}$ The drafters' intention in this regard is evident on the Act's face. However, the broadly drafted text of section 16 disguises the fact that the ADJR Act's remedial mechanisms have been construed narrowly, and conformably with common law judicial review principles, ${ }^{156}$ by courts for most of the Act's history.

This point can be made by reference to section 16(1)(a). At common law, the ordinary position is that a decision affected by jurisdictional error is treated as invalid from the date of the decision itself. ${ }^{157}$ In contrast, section 16(1)(a) of the ADJR Act provides a court with the discretion to make: 'an order quashing or

153 Ibid 46.

154 Minister for Immigration \& Multicultural Affairs; Ex parte Applicant S20/2002 (2003) 198 ALR 59, 94 [157] (Kirby J).

155 Administrative Review Council, above n 2, 76 [4.19]. The areas in which section 16 exceeds the 'amplitude of [the remedial] ... power' held by general law courts are set out in Robin Creyke, John McMillan and Mark Smyth, Control of Government Action: Text, Cases and Commentary (LexisNexis Butterworths, $4^{\text {th }}$ ed, 2015) 1121-2 [17.8.2].

156 Sometimes this is for the simple reason that the ADJR Act cannot 'transform the judicial review role of a court': Creyke, McMillan and Smyth, above n 155, 1122 [17.8.4].

157 Nguyen v Minister for Health and Ageing (2002) 121 FCR 89, 91 (Weinberg J). 
setting aside the decision, or a part of the decision, with effect from the date of the order or from such earlier or later date as the court specifies'.

That subsection was considered in Wattmaster Alco Pty Ltd $v$ Button, ${ }^{158}$ in which Pincus $\mathrm{J}$ employed this power to set aside an invalid customs declaration from the date of the Court's decision rather than from the earlier date of the declaration itself. His Honour noted the difference between the 'apparently unfettered discretion' to fix the date from which an order becomes operative under the $A D J R$ Act and the substantively different situation under the general law, ${ }^{159}$ holding that: "prima facie the setting aside should be operative from the date of the court's decision; a party desiring the specification of a different date must demonstrate the propriety of that course' ${ }^{160}$

On appeal, Sheppard and Wilcox JJ (with whom Fox J agreed on this point) viewed this as problematic, ${ }^{161}$ holding that the provision was 'intended to do no more than to indicate that the Court has a choice from all the available possibilities: the date of the order, an earlier date or a later date' ${ }^{162}$ Furthermore, their Honours noted that, although unusual in a general law order, there is no particular difficulty with making an administrative act or decision a nullity from a date other than that on which the act or decision first demonstrated jurisdictional error. ${ }^{163}$ The court's choice of a date should be guided only by the justice of the individual case, rather than any presumption as to the exercise of that discretion or the view that either party bears an onus to demonstrate why a particular date is appropriate. ${ }^{164}$ In deciding that the decision ought to be set aside from the date it was originally made, ${ }^{165}$ the Full Court was guided heavily by general law considerations, which had the practical effect of keeping the ADJR remedial scheme closer to that which would have been available under section 39B of the Judiciary Act 1903 (Cth). ${ }^{166}$

A preference for a common law reading of section 16 is also evident in the approach taken in Jadwan. ${ }^{167}$ That case recognised that 'retrospective nullification does not automatically follow from a court's conclusion that a decision was jurisdictionally flawed'. ${ }^{168}$ The Full Federal Court held that a

158 (1986) 8 FCR 471.

159 The common law remedial discretion also allows courts to delay their orders coming into effect: Aronson, Groves and Weeks, above n 3, 758-60 [10.360]-[10.365].

160 Wattmaster Alco Pty Ltd v Button (1986) 8 FCR 471, 480.

161 Wattmaster Alco Pty Ltd v Button (1986) 13 FCR 253, 255-6 ('Wattmaster Alco Appeal').

162 Ibid 256.

163 Ibid. See Aronson, Groves and Weeks, above n 3, 731-2 [10.20]-[10.30].

164 If the order does not stipulate a date, it is assumed under s 16(1)(a) that the operative date is the date of the order itself.

165 Wattmaster Alco Pty Ltd v Button (1986) 13 FCR 253, 259. See, however, criticism of the Full Court's lack of clarity in this regard: Jadwan Pty Ltd $v$ Secretary, Department of Health and Aged Care (2003) 145 FCR 1, 18 (Gray and Downes JJ) ('Jadwan').

166 There were also some practical issues around the fact that the appellant had already paid substantial sums of import duty, under protest, on the authority of the invalid order: Aronson, Groves and Weeks, above n $3,759-60$ [10.365].

167 (2003) 145 FCR 1.

168 Aronson, Groves and Weeks, above n 3, 740 [10.110]; approved in Lewis v Australian Capital Territory (2018) 329 FLR 267, 303 [202] (Refshauge J). 
nursing home's status as an 'approved provider' was able to be restored but, since it had never alleged the presence of a jurisdictional error or sought to have the cancellation of its status declared a nullity, any such restoration could be prospective only. The general law application of judicial review remedies essentially overruled a statutory regime whose whole point, successfully realised for 'the first decade or so' of its operation, ${ }^{169}$ was to operate beyond the limitations of jurisdictional error. ${ }^{170}$ Although the Full Court in Jadwan reached its conclusion for different reasons to those in Wattmaster Alco Appeal, it nonetheless indicated a preference for common law remedial concepts over those in section 16 of the $A D J R$ Act. ${ }^{171}$

These cases are helpful in the context of interpreting the scope of the courts' remedial power under section $16(1)(\mathrm{d})$ of the ADJR Act to '[direct] ... any of the parties to do ... any act or thing the doing ... of which the court considers necessary to do justice between the parties'. While the High Court has said that the 'scope of the powers to make orders which the subsection confers should not ... be constricted by undue technicality', ${ }^{172}$ this does not mean that the Court has been prepared to extend the scope of the ADJR Act's remedial provisions beyond that of the equivalent general law remedies. At the time when the ADJR Act was being drafted, it was recommended to the drafter that a provision be included which would enable the Federal Court to develop a damages remedy. However, the opposition to the ADJR Act as a whole was such that a specific provision for damages would have had no prospect of adoption and the plan for a damages remedy was dropped. It may be an unforeseen consequence of this choice that the remedies under the ADJR Act still cleave to the common law.

The litigation in the Park Oh Ho cases, which involved the unlawful detention of unlawful entrants into Australia in lieu of deportation, ${ }^{173}$ remains central to an understanding of the capacity of courts to award damages under this provision. At trial, ${ }^{174}$ Davies $\mathrm{J}$ held that the orders made to detain the applicants

169 Stephen Gageler, 'Impact of Migration Law on the Development of Australian Administrative Law' (2010) 17 Australian Journal of Administrative Law 92, 96.

170 However, there is an argument that the same reasoning will come into effect whenever an applicant seeks an order that the decision under challenge was not 'made under' the enactment in question: Jadwan (2003) 145 FCR 1, 17 (Gray and Downes JJ); Aronson, Groves and Weeks, above n 3, 81-2 [2.410].

171 In Grass v Minister for Immigration and Border Protection (2015) 231 FCR 128, 146-7 [77], Perram, Yates and Mortimer JJ expressed doubt whether an unlawful decision - 'especially where the error identified is of a jurisdictional kind' - could be set aside with effect from a future date under section 16(1)(a) where to do so would involve a court in preserving an unlawful decision. See also Minister for Immigration \& Ethnic Affairs v Conyngham (1986) 11 FCR 528; Park Oh Ho v Minister of State for Immigration and Ethnic Affairs (1989) 167 CLR 637; Johns v Australian Securities Commission (1993) 178 CLR 408.

172 Park Oh Ho v Minister of State for Immigration and Ethnic Affairs (1989) 167 CLR 637, 644 (Mason CJ, Deane, Toohey, Gaudron and McHugh JJ).

173 The applicants were held for the purpose of giving evidence in criminal proceedings relating to the people smuggling scheme under which they had entered the country. The statutory power to detain is both limited and purposive; see, eg, CPCF v Minister for Immigration and Border Protection (2015) 255 CLR 514, 539 (French CJ).

174 Park Oh Ho v Minister for Immigration and Ethnic Affairs (1988) 14 ALD 787. 
in the country for an ultra vires purpose were a nullity. ${ }^{175}$ However, in contrast to legislation allowing public bodies to be sued for damages in tort, ${ }^{176}$ he held that the text of section 16(1)(d) of the ADJR Act was insufficient to ground a right to damages, having established a ground of review under the Act. ${ }^{177}$

On appeal to the Full Federal Court, ${ }^{178}$ Morling J thought that 'doing justice' was limited to the review of the impugned decision rather than in relation to associated common law claims ${ }^{179}$ and confirmed that " $[t]$ he award of damages has never been held to be a remedy available in proceedings brought by way of judicial review'. ${ }^{180}$ Though the issue was not the subject of the subsequent grant of special leave to appeal to the High Court, ${ }^{181}$ it took the opportunity in a unanimous joint judgment to confirm that damages fell into a different category than other forms of relief, saying 'both declaratory and injunctive orders, as distinct from an order for damages, can readily be seen as appropriate remedies of judicial "review" of administrative decisions and actions'. ${ }^{182}$ The High Court allowed the appeals and ordered that the orders of Davies J be varied to include a declaration that the appellants' detention had been unlawful. ${ }^{183}$

A declaration that the applicants in the Park Oh Ho cases had been invalidly detained was practically important because such an order paved the way to making out the tort of false imprisonment, which is remedied by an order for damages. However:

recent judgments ... have said that only nominal damages should be awarded if the government party can show that it would in any event have lawfully imprisoned the plaintiff. The reasoning is that the plaintiff has actually lost nothing.

175 Ibid 791. However, his Honour declined to make a declaration to that effect, preferring to set the orders aside ab initio: at 792 .

176 See, eg, Judiciary Act 1903 (Cth) s 64. This provision removes the procedural bar to bringing suit for torts committed directly by the Crown, as opposed to exposure to vicarious liability for the torts of those it employs: Commonwealth v Mewett (1997) 191 CLR 471. Equivalent legislation exists in every

Australian jurisdiction; see Aronson, Groves and Weeks, above n 3, 1093-4 [19.70].

177 Park Oh Ho v Minister for Immigration and Ethnic Affairs (1988) 14 ALD 787, 789-90.

178 The three judges in the Full Federal Court would each have made different orders. Ultimately, both the appeals and cross appeals were dismissed, by differently comprised majorities. Each of the three judgments agreed, however, that damages were not available as a remedy under the ADJR Act: Park Oh Ho v Minister for Immigration \& Ethnic Affairs (1988) 20 FCR 104, 114 (Sweeney J), 126 (Morling J), 134 (Foster J).

179 Ibid 126-7 (Morling J).

180 Ibid 126.

181 The High Court's grant of special leave to appeal the decision of the Full Court of the Federal Court was limited to Davies J's decision to set aside the orders made to detain the applicants in the country for an ultra vires purpose as a nullity, rather than to make a declaration to that effect: Park Oh Ho v Minister for Immigration and Ethnic Affairs (1989) 167 CLR 637, 641-2, 644 (Mason CJ, Deane, Toohey, Gaudron and McHugh JJ).

182 Ibid 645. Note that the use of declaratory relief was, distinct from damages, specified as an 'appropriate' remedy.

183 Ibid 646.

184 Aronson, Groves and Weeks, above n 3, 750 [10.220] (citation omitted). See, eg, the discussion in Lewis $v$ Australian Capital Territory [2018] 329 FLR 267, 316-19 [316]-[339] (Refshauge J). 
The fact that the applicants in Park $\mathrm{Oh} \mathrm{Ho}$ were being detained for an invalid purpose and would otherwise have been deported should have been enough to overcome this concern.

One final issue deserves mention. In Johns $v$ Australian Securities Commission, ${ }^{185}$ Brennan J made the point that, when a public authority owes an equitable obligation and that obligation is breached, it can either be enforced by an injunction or remedied by damages under Lord Cairns' Act. ${ }^{186}$ The Supreme Court in each Australian jurisdiction has power granted in similar terms, in addition to the inherent power to award equitable compensation for the breach of a fiduciary or other equitable duty. ${ }^{187}$ These are remedies that fill a similar need to damages, although to say that the power to grant equitable compensation is used even sporadically, would be to overstate matters.

\section{CONCLUSION}

Taking into account the approach to damages adopted by the courts as outlined above, it appears that there is no prospect of the judiciary taking on the task of extending the remedial approach to existing causes of action, so as to provide a remedy in damages consequent upon the invalid exercise of public power. Therefore, if we are to see the development of such a remedy at any point in the near future, it will be legislatively, ${ }^{188}$ rather than judicially, driven. Any assessment on our part of the legislative appetite for such a development would be merely speculative (though we note that it has been much more usual in recent times for legislatures to reduce public authorities' tort liability than to increase it). ${ }^{189}$ Rather, we highlight these judicial misgivings as part of the more important task of weighing up the objections that will inevitably be made to the development of such a remedy more generally.

A number of proposals for law reform have been put forward with a view to providing a means of restoration for individuals who have been harmed as a result of government maladministration. Peter Cane was an early contributor to the debate, urging that we release our hold on the 'fundamental tenet' that damages are not available for breaches of public law rules, and instead direct our attention to whether there is anything in the nature of a remedy in damages that renders it unsuitable to the public law context (which in his view, there was not). ${ }^{190}$ Others have taken the matter a step further, in advocating the adoption of a particular remedial framework. Notable in this respect are the proposals put

185 (1993) 178 CLR 408, 429.

186 Chancery Amendment Act 1858 (21 \& 22 Vict c 27).

187 Greg Weeks, 'Estoppel and Public Authorities: Examining the Case for an Equitable Remedy' (2010) 4 Journal of Equity 247, 278-86.

188 Even an executive solution at Commonwealth level would need to be supported by legislation within a constitutional head of power; see Williams v Commonwealth (2012) 248 CLR 156; Williams v Commonwealth (2014) 252 CLR 416.

189 See above $\mathrm{n} 60$.

190 Cane, above $\mathrm{n} 85$. 
forward by Tom Cornford ${ }^{191}$ and the UK Law Reform Commission. ${ }^{192}$ It would be fair to say that responses to proposals such as these have been weighted more heavily against reform. We think that it is high time to revisit some of the core concerns that have been thrown up as roadblocks to the development of a remedy for public law wrongs, which range from the well-rehearsed pragmatic concerns about overkill and drain on public funds, to more nuanced concerns about incoherence in the law and even breach of the separation of powers. On closer inspection we may find that these are not so much insuperable barriers, but pitfalls that may be avoided by adopting a considered approach.

191 Tom Cornford, Towards a Public Law of Tort (Ashgate Publishing, 2008).

192 UK Law Commission, ‘Administrative Redress: Public Bodies and the Citizen’ (Consultation Paper No 187, 17 June 2008). 